\title{
Tissue Polypeptide Specific Antigen
}

National Cancer Institute

\section{Source}

National Cancer Institute. Tissue Polypeptide Specific Antigen. NCI Thesaurus. Code C17909.

An antigenic dimeric combination of intermediate filament Keratin 8 and Keratin 18 peptides, $\mathrm{K} 8 / \mathrm{K} 18$, which is detectable in serum and is being investigated as a cancer marker. 